\title{
Impact of Corporate Social Performance on Financial Performance: Case of Firms Listed on the Stock Exchange of Casablanca
}

\author{
Lamia Jamel $^{1}$, Monia Ben Ltaifa ${ }^{2}$, Ahmed K Elnagar ${ }^{3}$ \& Abdelkader Derbali $^{4}$ \\ ${ }^{1}$ Department of Finance and Economics, College of Business Administration, Taibah University, Saudi Arabia \\ ${ }^{2}$ Human Resource Department, Community College in Abqaiq, King Faisal University, Saudi Arabia \\ ${ }^{3}$ Assistant Professor at the Department of Administrative and Financial Sciences and Techniques, Community \\ College, Taibah University, Saudi Arabia; Suez Canal University, Egypt \\ ${ }^{4}$ Department of Administrative and Financial Sciences and Techniques, Community College, Taibah University, \\ Saudi Arabia. Department of Management Sciences, Higher Institute of Informatics and Management of Kairouan, \\ Kairouan University, Tunisia \\ Correspondence: Abdelkader Derbali, Department of Administrative and Financial Sciences and Techniques, \\ Community College, Taibah University, Box 2898, Medinah, 41461, Saudi Arabia. Tel: 966-543-495-251. E-mail: \\ derbaliabdelkader@outlook.fr
}

Received: May 15, 2020 Accepted: June 9, 2020 Online Published: June 17, 2020

\begin{abstract}
This paper examines empirically the impact of corporate social performance (CSP) on financial performance (FP). The study relates to a panel of 32 firms listed on the Stock Exchange of Casablanca during the period of study from 2011 to 2017. The empirical findings obtained, by linear regressions on panel data, clearly find the lack of impact of the corporate social performance on the financial performance measured by the Return on Investment (ROI), Return on Equity (ROE) and Earnings Per Share (EPS) ratios. The influence of corporate social performance on financial performance is statistically insignificant. The financial performance of firms classified or not socially efficient are almost identical. Finally, the results obtained clearly show the absence of this causal link between corporate social performance (CSP) on financial performance (FP), which confirms the research hypothesis. Finally, since the relationship between these two performances could be non-linear, we can deepen this article using econometric methods that can analyze the non-linear effect such as quantile regression and the regimechange model.
\end{abstract}

Keywords: company social performance, financial performance, top performers, panel data

\section{Introduction}

Faced with the resurgence of different financial scandals, the question of ethics in finance has become a major issue for the various economic players. The articulation between ethics and finance continues to be widely debated by researchers. The considering of an ethical reference in finance is declined in solidarity finance, CSR, SRI, Islamic finance, etc.

But the question that arises can we reconcile ethics and performance or in other words does ethical commitment penalize performance (Saadaoui, 2008). The answer to this question has been the subject of a multitude of scientific contributions comparing the performance of:

- Ethical and conventional funds, such as the work carried out by Kreander et al. (2005), Leite and Cortez (2018) and Kiymaz (2019).

- Ethical and conventional indices, like the research conducted by Mollet and Ziegler (2014), Blankenberg and Gottschalk (2018) and Jawadi et al. (2019).

- And socially responsible (SR) and non-SR companies, such as the scientific contributions of Lee et al. (2009), Wang et al. (2016), and Chetty et al. (2015).

This article is part of this third approach by trying to study the impact of corporate social performance (CSP) on financial performance (FP) in the Moroccan context.

Given the growing interest of researchers and economic players in this theme, and given the scarcity of work devoted, in Morocco, to examining this impact, this article aims to respond to the following problem: 
To what extent does the CSP influence the FP of Moroccan companies listed on the Stock Exchange of Casablanca (CSE)?

Unlike the work carried out by El Malki (2010), Mouatassim and Ibenrissoul (2016) and El Yaagoubi (2019), dealing only with the influence of CSR on FP, the objective of this article is to analyze the link between CSP and FP on a panel of 32 companies listed on the CSE, covering the period from 2011 to 2017, taking into account their social rating assigned by Vigeo.

This problem is treated according to a positivist epistemological positioning based on a quantitative study. The data, extracted from financial statements published by MCMA (Moroccan Capital Market Authority), were subjected to statistical processing by Eviews.

The empirical methodology used is the econometrics of panel data by performing linear regressions, using Least Square Methods, Fixed Effects Methods and Random Effects Methods.

To provide elements of response to our problem, we present in a second section the theoretical foundations of our problem. In a third section, we present the results of the empirical analysis, highlighting the conceptual model of the research, the variables used, and the results obtained. Finally, section 4 concludes.

\section{Literature Review}

In order to study this link, we first define the concept of CSP and then present the different measures used to assess it.

\subsection{Company Social Performance}

When we try to define CSP, this concept is not stabilized. It is a word "suitcase" which has received and still receives many meanings according to the authors.

For Allouche and Laroche (2013), methodological or even epistemological problems or vagueness surround the attempt to operationalize the CSP and reflect a feeling of heavy conceptual fragility. Although CSP remains a concept with fuzzy and evolving borders. Three conceptual models are often cited to apprehend this notion.

The first presents the CSP, as a three-dimensional articulation between different categories of social responsibilities (economic, legal, ethical and discretionary), specific problems linked to these responsibilities (environment, discrimination, product safety, work safety, shareholding) and philosophies of response to these problems: reactive, defensive, accommodative or proactive (Carroll, 1979).

The second model defines it as a configuration of the principles of social responsibility, the processes of social sensitivity and observable programs, policies and results relating to corporate social relations (Wood, 1991).

For the latter, CSP is the ability of the company to manage and satisfy its stakeholders: employees, owners / shareholders, consumers, suppliers, competitors and public authorities (Clarkson, 1995).

These models distinguish the dimensions of CSP on which a company must rely, the management principles it must deploy and ultimately the results it obtains in terms of CSP. However, they do not offer any measure to measure this performance.

\subsection{CSP Assessment Measures}

There is currently no universal definition or consensus on the measurement of CSP. Different measures are used to assess it such as pollution indices, reputation indices, the amount of charitable donations, the environmental score and measures by rating bodies, etc. (Tebini, 2013).

Igalens and Gond (2005) present five types of approaches to measure CSP (table 1).

Table 1. Characteristics and relevance of the main CSP measures

\begin{tabular}{cccc}
\hline $\begin{array}{c}\text { Type of } \\
\text { measurement }\end{array}$ & $\begin{array}{c}\text { Relevance to the concept of } \\
\text { CSP }\end{array}$ & Features / Problems & Production mode \\
\hline $\begin{array}{c}\text { Content of annual } \\
\text { reports }\end{array}$ & $\begin{array}{c}\text { A more symbolic than } \\
\text { substantive measure } \\
\text { (discourse) which does not } \\
\text { refer to the different } \\
\text { dimensions of the construct }\end{array}$ & $\begin{array}{c}\text { Easy-to-handle } \\
\text { subjective measurement }\end{array}$ & By the company \\
\hline $\begin{array}{c}\text { Pollution } \\
\text { indicators }\end{array}$ & $\begin{array}{c}\text { Measure only one of the } \\
\text { dimensions of the construct }\end{array}$ & $\begin{array}{c}\text { Measure - target that } \\
\text { does not apply to all }\end{array}$ & $\begin{array}{c}\text { By an organization } \\
\text { external to the firm }\end{array}$ \\
\hline
\end{tabular}




\begin{tabular}{|c|c|c|c|}
\hline & (environment) & businesses & \\
\hline $\begin{array}{l}\text { Questionnaire } \\
\text { surveys }\end{array}$ & $\begin{array}{l}\text { Depends on the proposed } \\
\text { measures; possibility of a } \\
\text { strong fit to the concept but } \\
\text { these measures primarily } \\
\text { reflect the perceptions of the } \\
\text { actors }\end{array}$ & $\begin{array}{l}\text { Perceptual measurement } \\
\text { which can give rise to } \\
\text { possibilities of } \\
\text { manipulation linked to } \\
\text { the mode of } \\
\text { administration }\end{array}$ & $\begin{array}{l}\text { By the researcher who } \\
\text { collects them directly } \\
\text { from the company by } \\
\text { questionnaire }\end{array}$ \\
\hline $\begin{array}{l}\text { Reputation } \\
\text { indicators }\end{array}$ & $\begin{array}{l}\text { Confusion with the notion of } \\
\text { reputation, ambiguity }\end{array}$ & Perceptual measurement & $\begin{array}{l}\text { By an organization } \\
\text { external to the firm }\end{array}$ \\
\hline $\begin{array}{c}\text { Data produced by } \\
\text { measurement } \\
\text { organizations }\end{array}$ & $\begin{array}{l}\text { Multidimensional } \\
\text { measurement, the degree of } \\
\text { adequacy to the theoretical } \\
\text { models depends on the } \\
\text { working mode and the } \\
\text { reference frames mobilized by } \\
\text { these }\end{array}$ & $\begin{array}{l}\text { Depends on how } \\
\text { agencies work }\end{array}$ & $\begin{array}{l}\text { By an organization } \\
\text { external to the firm }\end{array}$ \\
\hline
\end{tabular}

Source: Igalens and Gond (2005)

We find that the five methods use different measures, the first four use secondary data, while the last is based on primary data. These methods can be influenced by the methodology of their production and the origin of the data used. This could pose a problem of subjectivity and reliability of the information disseminated.

After having presented the concept and the evaluation measures of CSP, we deal in the next section with the main FP indicators used.

\subsection{FP Indicators}

To analyze this link, several FP indicators are used to assess it. Based on a meta-analysis of 122 studies relating to this relationship, Margolis and Walsh (2003) identify 70 measures grouped into two categories:

- Accounting measures such as: ROA, ROE, EPS, etc.

- Market measures: Q of Tobin, MVA, MBV, etc.

However, these indicators, used separately or concomitantly, are subject to numerous biases. The accounting measures give a historical idea of the evaluation of the profitability of the company and depend on the accounting methods put in place and are easily manipulated. While market measures inevitably incorporate market characteristics and risks that are not specific to a company (Bnouni, 2011).

\subsection{Link between CSP and FP}

The relationship between CSP and FP has been the subject of an abundant literature since the 1970s, according to:

- The nature of this relationship: linear, non-linear, direct, and indirect.

- The meaning of this relationship: is that CSP which influences FP or the opposite or is it a reciprocal relationship.

- The sign of this relationship: positive, negative, or neutral.

Preston and O'Bannon (1979), illustrated this relation by the table 2.

Table 2. Typology of the relationship between CSP and FP

\begin{tabular}{lcc}
\hline Causality & Positive & Negative \\
\hline $\begin{array}{c}\text { Social impact hypothesis. } \\
\text { Satisfying the needs of the various } \\
\text { stakeholders of the company will serve to } \\
\text { spread its good reputation and positively } \\
\text { impact its FP. }\end{array}$ & $\begin{array}{c}\text { Arbitration assumption. } \\
\text { The implementation of socially responsible } \\
\text { practices generates financial costs which } \\
\text { could be the source of a competitive } \\
\text { disadvantage and a deterioration in financial } \\
\text { profitability over time. }\end{array}$ \\
\hline FP $\Rightarrow$ & $\begin{array}{c}\text { Assumption of available funds. } \\
\text { A high level of financial profitability } \\
\text { allows the company to increase its }\end{array}$ & $\begin{array}{c}\text { Ophentunism hypothesis. } \\
\text { to increase their own profit by reducing }\end{array}$ \\
\hline
\end{tabular}




\begin{tabular}{cc}
\hline $\begin{array}{c}\text { financial capacity allowing it to implement } \\
\text { discretionary societal practices, which will } \\
\text { have the consequence of increasing its } \\
\text { CSP. }\end{array}$ & $\begin{array}{c}\text { social spending. Conversely, when FP is } \\
\text { falling, this deficit can be offset by an } \\
\text { increase in social spending which will lead } \\
\text { to an increase in CSP, to divert attention. }\end{array}$ \\
\hline $\begin{array}{c}\text { Positive synergy. } \\
\text { A high level of CSP leads to an } \\
\text { FP }\end{array}$ & $\begin{array}{c}\text { Negative synergy. } \\
\text { possibility of reinvesting in socially } \\
\text { responsible actions. This creates a } \\
\text { simultaneous and interactive relationship } \\
\text { forming a virtuous circle. }\end{array}$ \\
\hline
\end{tabular}

Source: Preston and O’Bannon (1997)

By subscribing to this typology, a multitude of scientific contributions have tried to establish this link. For some authors, such as Manrique and Martí-Ballester (2017), Choi et al. (2018) and Laskar (2018), CSP has a positive impact on FP. On the other hand, for others, this impact is negative, like Brammer et al. (2006), Masoud and Halaseh (2017), Han et al. (2016) and Ngoc (2018).

The lack of consensus on the nature of this relationship has opened the way to another stream of work, which highlights a lack of link between these two performances. For vision supporters such as Moses et al. (2014), Strouhal et al. (2015) and Maqbool and Bakr (2019), this influence would be difficult to establish, given the multiplicity of variables involved.

This divergence of results leads us to formulate the following central research hypothesis:

$H$ : The social performance of the company has no impact on financial performance.

This hypothesis is tested according to the research model presented in the following section.

\section{Empirical Analysis}

We begin by presenting the research model and the results of the empirical analysis.

\subsection{Conceptual Model of Research}

To understand this link, we have chosen a sample made up of a cylinder panel of 32 companies listed on the SEC over the period from 2011 to 2017. These companies which are the subject of our study are selected based on their social performance depending on the rating awarded by Vigeo.

The dependent variable of our model is FP illustrated by 3 ratios commonly used in the literature:

- Economic profitability or ROI (return on investment) = Net income / Total assets.

- Financial profitability or ROE (return on Equity) = Net income / Equity.

- And Earnings per share $=$ Net earnings $/$ Number of shares.

The various financial information required to calculate these ratios is extracted from the financial statements published on the SEC and MCMA websites.

The explanatory variable (CSP) is a dichotomous or binary variable, depending on whether the companies are classified as Top Performers (Top P) by Vigeo. The companies classified Top P obtain the best social rating, those achieving a bad score are said not Top P.

This rating is assigned according to a benchmark of 38 criteria and more than 330 indicators in the following six areas: respect for human rights, enhancement of human capital, environmental protection, business ethics, the efficiency and independence of governance and their commitment to the development of their areas of activity.

Based on the literature review, we use as moderating variables, the size of the company expressed for the logarithm of turnover and two capital structure ratios, the first relating debts to LT to total liabilities and the second equity to the same denominator. The research model looks like this in the figure 1: 


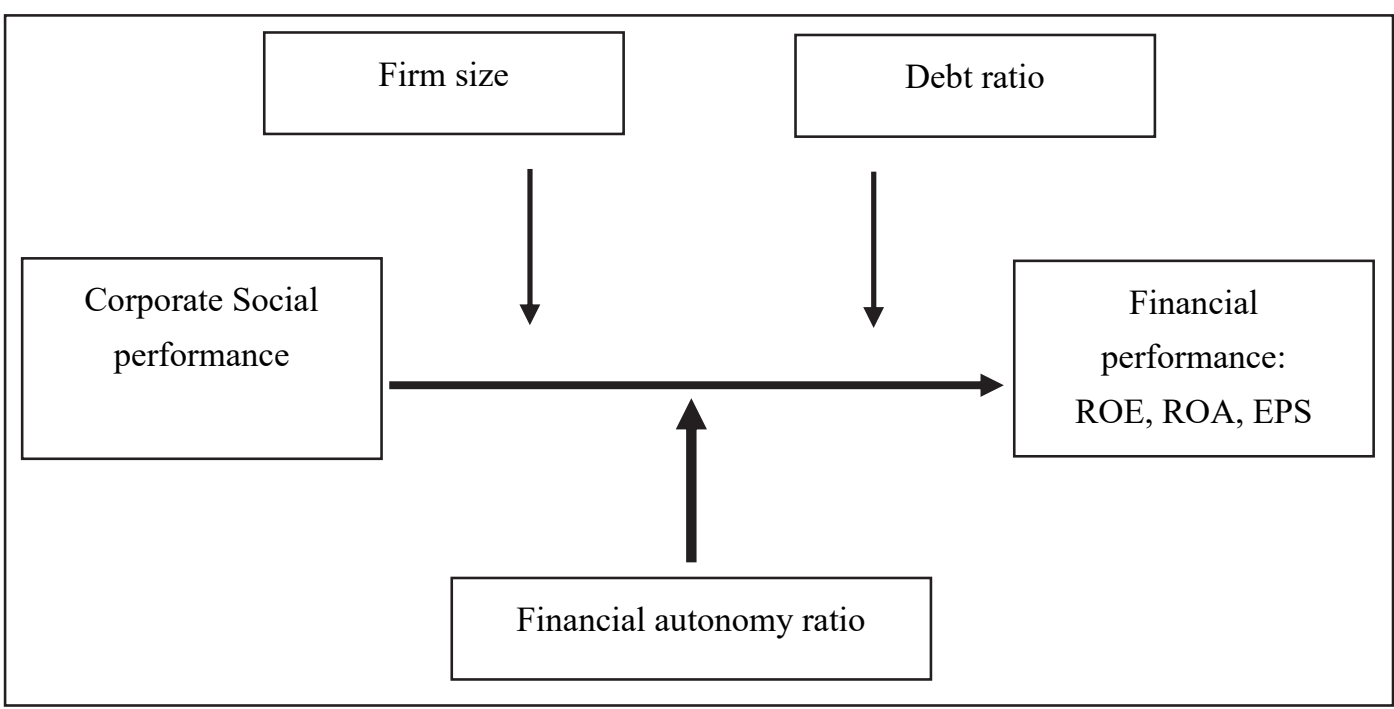

Figure 1. Conceptual model of research

Source: Own Elaboration

The estimated model is presented as follow:

$$
\mathbf{F P}=\alpha+\beta_{1} \mathbf{C S P}+\beta_{\mathrm{i}} \mathbf{X}+\varepsilon
$$

Where, FP is a financial performance indicator selected each time, $\alpha$ is a constant, CSP is an explanatory variable indicating the social performance of the company, $\mathrm{X}$ is a matrix of control variables likely to explain the company's financial performance and $\varepsilon$ in an error terms.

The table 3 shows these different variables:

Table 3. Variables of the conceptual research model

\begin{tabular}{ccc}
\hline \multirow{2}{*}{$\begin{array}{c}\text { Dependent variable } \\
\text { Explicative variable }\end{array}$} & FP & Earnings per share: EPS \\
\cline { 3 - 3 } & & ROE \\
\hline Control variables & CSP & ROI \\
\cline { 2 - 3 } & Financial autonomy ratio & 1 if the firm is Top P \\
\hline Source: Own Elaboration & Ratio of debt & Equity / Total Liabilities \\
\hline
\end{tabular}

\subsection{Descriptive Statistics}

To verify this impact, we are carrying out a comparative analysis of the three sample ratios according to the agency's reporting schedule.

\subsubsection{Relationship between CSP and ROE}

The ROE calculation for socially classified or non-performing companies gives us the results presented in the table 4.

Table 4. ROE as a function of CSP (\%)

\begin{tabular}{ccccccccc}
\hline & \multicolumn{2}{c}{2011} & \multicolumn{2}{c}{2013} & \multicolumn{2}{c}{2015} & \multicolumn{2}{c}{2017} \\
\cline { 2 - 10 } & Top P* & NTP** & Top P & NTP & Top P & NTP & Top P & NTP \\
\hline Mean & 12.81 & 7.25 & 12.80 & 7.12 & 10.79 & 4.38 & 7.55 & 5.55 \\
\hline Median & 12.47 & 4.23 & 9.30 & 6.03 & 7.37 & 6.25 & 9.63 & 7.46 \\
\hline
\end{tabular}




\begin{tabular}{ccccccccc}
\hline Max & 23.47 & 31.83 & 27.10 & 36.83 & 30.48 & 23.51 & 14.17 & 17.61 \\
\hline Min & 1.72 & -15.01 & 1.85 & -1.71 & 1.49 & -17.06 & 0.33 & -14.26 \\
\hline Std. Div & 9.20 & 9.48 & 10.65 & 7.58 & 9.91 & 8.11 & 4.75 & 6.94 \\
\hline
\end{tabular}

Note: * Top P: top performers ** NTP: Non-top performers

Source: Own Elaboration

The average ROE of Top P companies is higher than that of NTP companies. Similarly, we find:

- A downward trend in the average between 2011 and 2017 for both Top P companies and NTPs;

- Strong heterogeneity of results for ROE (Standard deviation represents almost 100\% of the average, over the four years).

3.2.2 Relationship between CSP and ROI

The calculation of the ROI of socially classified or non-performing companies gives us the results presented in the table 5 .

Table 5. ROI as a function of CSP (\%)

\begin{tabular}{ccccccccc}
\hline & \multicolumn{2}{c}{2011} & \multicolumn{2}{c}{2013} & \multicolumn{2}{c}{2015} & \multicolumn{2}{c}{2017} \\
\cline { 2 - 9 } Top P* & NTP** & Top P & NTP & Top P & NTP & Top P & NTP \\
\hline Mean & 32.16 & 12.04 & 25.66 & 13.47 & 23.51 & 15.88 & 17.58 & -7.11 \\
\hline Median & 33.39 & 10.80 & 21.49 & 13.30 & 15.66 & 11.39 & 17.17 & 10.19 \\
\hline Max & 56.09 & 49.73 & 51.87 & 44.82 & 55.46 & 229.17 & 37.10 & 52.20 \\
\hline Min & 6.05 & -36.11 & 6.77 & -7.02 & 10.04 & -89.23 & 0.78 & -410.53 \\
\hline Std. Div & 19.20 & 15.62 & 15.66 & 11.30 & 17.50 & 49.10 & 10.28 & 91.02 \\
\hline
\end{tabular}

Note: * Top P: top performers ** NTP: Non-top performers

Source: Own Elaboration

The return on equity of Top P companies is higher than that of NTP. However, we note that the dispersion of the observations is quite large and that the results are heterogeneous.

3.2.3 Relationship between CSP and EPS

The calculation of EPS of socially classified or socially ineffective companies gives us the results presented in the table 6.

Table 6. EPS as a function of CSP (\%)

\begin{tabular}{ccccccccc}
\hline & \multicolumn{2}{c}{2011} & \multicolumn{2}{c}{2013} & \multicolumn{2}{c}{2015} & \multicolumn{2}{c}{2017} \\
\cline { 2 - 9 } & Top P* & NTP** & Top P & NTP & Top P & NTP & Top P & NTP \\
\hline Mean & 33.74 & 42.46 & 67.15 & 35.73 & 55.95 & 20.08 & 41.01 & 35.29 \\
\hline Median & 22.27 & 10.55 & 17.49 & 15.84 & 34.65 & 7.05 & 20.39 & 13.61 \\
\hline Max & 87.41 & 243.90 & 309.67 & 219.96 & 142.33 & 116.38 & 145.27 & 158.08 \\
\hline Min & 9.26 & -66.92 & 6.03 & -7.58 & 6.75 & -87.41 & 6.21 & -83.71 \\
\hline Std. Div & 29.47 & 73.57 & 110.02 & 50.28 & 49.83 & 48.74 & 46.20 & 56.27 \\
\hline
\end{tabular}

Note: * Top P: top performers ** NTP: Non-top performers

Source: Own Elaboration

The market profitability expressed in EPS of Top P companies is higher than that of NTP. However, to better compare the means of two samples (Top P and NTP) for the three ratios, we used the ANOVA analysis of variance based on the Fisher test, below with the hypothesis H0: the two means are equal. 
Table 7. Fisher test of FP ratios

\begin{tabular}{cccc}
\hline Ratios & df & Value & Probability \\
\hline ROE & $(1,127)$ & 6.926928 & 0.0095 \\
\hline ROI & $(1,127)$ & 2.417639 & 0.1225 \\
\hline EPS & $(1,127)$ & 1.667605 & 0.1989 \\
\hline
\end{tabular}

Source: Own Elaboration

For ROE, the probability associated with the F statistic is below the critical threshold of 5\%. We reject $\mathrm{H} 0$ and accept the alternative hypothesis which states that the two means are statistically different, which confirms our first observation.

For ROI and EPS, the probabilities associated with the F statistic are higher than the critical threshold of 5\%. We reject $\mathrm{H} 0$ from the statistical equality of the two means, which invalidates our first observations relating to these two ratios.

These different results allow us to see that the average ROE of Top P companies is higher than that of companies with NTP. However, for the other two indicators (ROI and EPS), Top P companies achieve the same levels of profitability as NTP companies.

However, this simple comparison of the means does not allow us to qualify this link, hence the interest in carrying out econometric models to confirm or confirm these observations.

\subsection{Stationarity TEST}

We also conduct a test of the unit root panel data. Thus, we used the test Levin Lin Chu. The null hypothesis of this test is H0: all series are non-stationary and the alternative hypothesis is H1: all series are stationary. The acceptance or rejection of the null hypothesis is based on the value of the p-value.

This value is compared to a $10 \%$ threshold. If the value of the p-value is less than $10 \%$, then we reject H0 and the value of the p-value is greater than $10 \%$, while we accept H0. Table 8 summarizes the results of study of the stationary of the variables.

In our case, we notice that all the variables used herein p-value of less than $10 \%$. In this case, one rejects $\mathrm{H} 0$ and thereafter all these variables are stationary.

Table 8 . Test the unit root

\begin{tabular}{ccc}
\hline Variables & Statistic & p-value \\
\hline ROE & -3.5395 & 0.0002 \\
ROI & -2.8474 & 0.0022 \\
EPS & -1.7158 & 0.0431 \\
TOP PERF & -4.3599 & 0.0000 \\
Size & -5.0001 & 0.0000 \\
Financial autonomy ratio & -4.4979 & 0.0000 \\
Debt ratio & -6.3591 & 0.0000 \\
Note: In this test the p-value is compared to 10\%. If p-value $<10 \%$ therefore we reject H0 and p-value $>$ \\
10\% then we accept H0. With H0: all series are non-stationary. \\
Source: Own Elaboration
\end{tabular}

\subsection{Results}

To test the research hypothesis originally formulated, we used three main regression models of panel data. For each model, three estimation methods are used:

- Least Square Method: assuming that the parameters of the model to be estimated are homogeneous for all the companies in the sample.

- Fixed Effects Method: under the assumption of the impact of the explanatory variables while the constant is specific for each company. and

- Methods with Random Effects: under the assumption that the impact of the explanatory variables as well as the constant is not deterministic. 


\subsubsection{Regression Analysis}

The results of the econometric models relating to each financial performance ratio, are presented in the table 9 .

Table 9. Results of the regression models

\begin{tabular}{|c|c|c|c|c|}
\hline & Variables & LSM & FEM & REM \\
\hline \multirow{10}{*}{ ROE } & TOP_PERF & $\begin{array}{l}0.566686^{*} \\
(0.308856) \\
\end{array}$ & $\begin{array}{l}-0.368941 \\
(0.340560) \\
\end{array}$ & $\begin{array}{l}-0.086673 \\
(0.291920) \\
\end{array}$ \\
\hline & Size & $\begin{array}{c}1.826123 * * * \\
(0.371499) \\
\end{array}$ & $\begin{array}{c}4.936237 * * * \\
(1.356057) \\
\end{array}$ & $\begin{array}{c}2.278659 * * * \\
(0.534720) \\
\end{array}$ \\
\hline & $\begin{array}{c}\text { Financial } \\
\text { autonomy ratio }\end{array}$ & $\begin{array}{c}0.241870 * * * \\
(0.030515)\end{array}$ & $\begin{array}{c}0.158211 * * \\
(0.072454)\end{array}$ & $\begin{array}{c}0.220354 * * * \\
(0.041049)\end{array}$ \\
\hline & Debt ratio & $\begin{array}{l}-0.068600 \\
(0.045421)\end{array}$ & $\begin{array}{c}-0.207488 * * \\
(0.081600)\end{array}$ & $\begin{array}{c}-0.126630 * * \\
(0.054665)\end{array}$ \\
\hline & Constant & $\begin{array}{c}-42.61009 * * * \\
(8.523451)\end{array}$ & $\begin{array}{c}-101.7753 * * * \\
(29.31305)\end{array}$ & $\begin{array}{c}-49.87003 * * * \\
(12.14478)\end{array}$ \\
\hline & $\mathrm{R}^{2}$ & 0.466138 & 0.818093 & 0.332453 \\
\hline & $\mathrm{R}^{2}$-adjusted & 0.448917 & 0.746912 & 0.310919 \\
\hline & F-statistic & 27.06748 & 11.49315 & 15.43865 \\
\hline & Prob(F-statistic) & 0.000000 & 0.000000 & 0.000000 \\
\hline & $\mathrm{N}$ & 129 & 129 & 129 \\
\hline \multirow{10}{*}{ ROI } & TOP_PERF & $\begin{array}{c}1.139747 \\
(2.180974)\end{array}$ & $\begin{array}{c}0.778304 \\
(3.591571) \\
\end{array}$ & $\begin{array}{c}1.139747 \\
(2.207362)\end{array}$ \\
\hline & Size & $\begin{array}{c}6.962954 * * * \\
(2.623329) \\
\end{array}$ & $\begin{array}{c}55.72876^{* * * *} \\
(14.30108) \\
\end{array}$ & $\begin{array}{c}6.962954 * * * \\
(2.655069)\end{array}$ \\
\hline & $\begin{array}{c}\text { Financial } \\
\text { autonomy ratio }\end{array}$ & $\begin{array}{c}0.27153 \\
(0.215482)\end{array}$ & $\begin{array}{l}-0.992730 \\
(0.764101)\end{array}$ & $\begin{array}{c}0.271537 \\
(0.218089)\end{array}$ \\
\hline & Debt ratio & $\begin{array}{l}-0.472521 \\
(0.320737)\end{array}$ & $\begin{array}{c}-2.523056 * * * \\
(0.860560)\end{array}$ & $\begin{array}{c}-0.472521 \\
(0.324617)\end{array}$ \\
\hline & Constant & $\begin{array}{c}-142.4360 * * \\
(60.18806) \\
\end{array}$ & $\begin{array}{c}-1084.359 * * * \\
(309.1376) \\
\end{array}$ & $\begin{array}{c}-142.4360 * * \\
(60.91627) \\
\end{array}$ \\
\hline & $\mathrm{R}^{2}$ & 0.100354 & 0.316272 & 0.100354 \\
\hline & $\mathrm{R}^{2}$-adjusted & 0.071333 & 0.048726 & 0.071333 \\
\hline & F-statistic & 3.458003 & 1.182121 & 3.458003 \\
\hline & Prob(F-statistic) & 0.010259 & 0.258833 & 0.010259 \\
\hline & $\mathrm{N}$ & 129 & 129 & 129 \\
\hline \multirow{10}{*}{ EPS } & TOP_PERF & $\begin{array}{c}2.164516 \\
(2.590492) \\
\end{array}$ & $\begin{array}{l}-4.127447^{*} \\
(2.306309)\end{array}$ & $\begin{array}{c}-2.840234 \\
(2.109981) \\
\end{array}$ \\
\hline & Size & $\begin{array}{c}13.14090 * * * \\
(3.115907) \\
\end{array}$ & $\begin{array}{c}37.94549 * * * \\
(9.183361) \\
\end{array}$ & $\begin{array}{c}19.38229 * * * \\
(4.738596) \\
\end{array}$ \\
\hline & $\begin{array}{c}\text { Financial } \\
\text { autonomy ratio }\end{array}$ & $\begin{array}{c}1.356815 * * * \\
(0.255943) \\
\end{array}$ & $\begin{array}{c}1.055158 * * \\
(0.490663)\end{array}$ & $\begin{array}{c}1.242110^{* * *} \\
(0.341959) \\
\end{array}$ \\
\hline & Debt ratio & $\begin{array}{c}0.220070 \\
(0.380961) \\
\end{array}$ & $\begin{array}{l}-0.244047 \\
(0.552604)\end{array}$ & $\begin{array}{l}-0.080142 \\
(0.432724) \\
\end{array}$ \\
\hline & Constant & $\begin{array}{c}-309.5666 * * * \\
(71.48947) \\
\end{array}$ & $\begin{array}{c}-807.5681 * * * \\
(198.5111) \\
\end{array}$ & $\begin{array}{c}-428.2092 * * * \\
(0.432724) \\
\end{array}$ \\
\hline & $\mathrm{R}^{2}$ & 0.253858 & 0.834257 & 0.188958 \\
\hline & $\mathrm{R}^{2}$-adjusted & 0.229789 & 0.769400 & 0.162795 \\
\hline & F-statistic & 10.54703 & 12.86319 & 7.222428 \\
\hline & Prob(F-statistic) & 0.000000 & 0.000000 & 0.000029 \\
\hline & $\mathrm{N}$ & 129 & 129 & 129 \\
\hline
\end{tabular}

Note: $* * * \mathrm{p}<0.01 * * \mathrm{p}<0.05 * \mathrm{p}<0.10$

Source: Own Elaboration 
To choose the model with the best estimate, we perform the Hausman specification test:

\subsubsection{Specification Test}

The Hausman test allows a choice to be made between the fixed effect model and the random effect model. The Hausman test is based on the following assumptions: H0: Presence of random effects and H1: Presence of fixed effects.

Table 10. Hausman test

\begin{tabular}{cccc}
\hline & Chi-Sq. Statistics & Chi-Sq.d.f. & Prob. \\
\hline ROE & 13.212478 & 4 & 0.0103 \\
\hline ROI & 21.498764 & 4 & 0.0003 \\
\hline EPS & 8.708091 & 4 & 0.0688 \\
\hline
\end{tabular}

Source: Own Elaboration

For ROE and ROI, the $\mathrm{P}$ is less than 0.05 , we reject the null hypothesis to select the random Effects model. For EPS, $\mathrm{P}=0.0688$ is close to 0.05 , we accept the hypothesis 1 to select the Fixed Effects model.

\subsection{Discussion}

For the first ratio (ROE), the model is significant at the $1 \%$ threshold with $F=11,493$. Its fit quality is very good with $\mathrm{R} 2=82 \%$. The explanatory variable is negative and not significant $(\mathrm{p}=0.28)$ indicating the absence of a relationship between CSP and ROE.

The two moderating variables, size, and the financial autonomy ratio, positively contribute to performance, while the debt ratio influences it negatively. For the second indicator (ROI), the model is not statistically significant. No reliable interpretation can be made based on these estimates.

For the last ratio (EPS), the model is significant at the $1 \%$ threshold with $\mathrm{F}=12,863$. The fit of the model is very good. The explanatory variable is negative and statistically significant, which notes the existence of an absence of relation between CSP and EPS.

Among the control variables, only the size of the company and the financial autonomy ratio contribute positively to performance.

Empirical analysis shows an absence of causal link between these two performances. The regression models formulated highlight the absence of a significant difference in FP between the companies classified Top P and NTP.

These results are corroborated by the conclusions of the work carried out by Bouslah et al. (2006), who point out that the interaction model between these two performances may not be discovered from the available statistical data. Likewise, for Nelling and Webb (2009), there is no evidence of this relationship and if socially responsible activities bring benefits to the enterprise, they seem to manifest themselves in forms independent of FP.

\section{Conclusion}

The objective of this study is to empirically verify the potential link between CSP and FP in the Moroccan context. Neither the theoretical literature review nor the empirical results of the various research allow us to decide on the existence of this relationship. Faced with this observation, we hypothesized that there was no relationship between these two performances. Based on a conceptual model, we tested the research hypothesis on a sample of 32 Moroccan firms listed on the SEC from 2011 to 2017. For the three FP indicators (ROE, ROI, and EPS), the results obtained clearly show the absence of this causal link, which confirms the research hypothesis.

Our conclusions are different from the results of studies conducted in the Moroccan context, which maintain that this link is positive and / or negative. However, this study is not without limits; the first relates to the size of the sample, the second relates to the nature of this relationship which could be undisclosed from the available statistical data, and the last is that the measure of CSP adopted would risk masking this relationship.

In future research, it would be interesting to take into account other indicators of FP (such as Tobin's Q, MVA and MBV) and CSP, to integrate other control variables (such as the sector activity, research and development expenses, and the age of the business).

Finally, since the relationship between these two performances could be non-linear, we can deepen this article using econometric methods that can analyze the non-linear effect such as quantile regression and the regimechange model. 


\section{Acknowledgements}

The authors wish to thank the Editor in Chief and the anonymous referees whose valuable comments significantly improve the quality of the paper.

\section{References}

Allouche, J., \& Laroche, P. (2013). Corporate social responsibility and financial performance: a synthesis of the literature. HAL. pp.44. Retrieved from https://hal.archives-ouvertes.fr/hal-00830582

Blankenberg, A. K., \& Gottschalk, J. F. (2018). Is socially responsible investing (SRI) in stocks a competitive capital investment? A comparative analysis based on the performance of sustainable stocks. Center for European, Governance and Economic Development Research Discussion Papers, No. 349. Retrieved from http:/hdl.handle.net/10419/178700

Bnouni, I. (2011). Social performance and financial performance: State of the art. Presentation presented at the 20th AIMS Conference 2011.

Bouslah, K., M'zali, B., Kooli, M., \& Turcotte, M. F. (2006). Social and environmental responsibility, certifications and financial performance. Management, 27(3), 125-133. https://doi.org/10.1002/csr.1899

Brammer, S., Brooks, C., \& Pavelin, S. (2006). Corporate Social Performance and Stocks Returns: UK Evidence from Disaggregate Measures. Financial Management, 35(3), 97-116. https://doi.org/10.1111/j.1755053X.2006.tb00149.x

Carroll, A. B. (1979). A three-dimensional conceptual model of Corporate Social Performance. Academy of Management Review, 4(4), 497-505. https://doi.org/10.5465/amr.1979.4498296

Chetty, S., Naidoo, R., \& Seetharam, Y. (2015). The Impact of corporate social responsibility on firm's financial performance in South Africa. Contemporary Economics, 9(2), 193-214. https://10.5709/ce.1897-9254.167

Choi, J.H., Kim, S., \& Yang, D. H. (2018). Small and medium enterprises and the relation between social performance and financial performance: Empirical evidence from Korea. Sustainability, 10(6), 1816. https://doi.org/10.3390/su10061816

Clarkson, M. B. E. (1995). A stakeholder framework for analyzing and evaluating corporate social performance. Academy of Management Review, 20(1), 92-117. https://doi.org/10.5465/amr.1995.9503271994

El Yaagoubi, J. (2019). Impact of the social responsibility of companies listed on the Casablanca stock exchange on their financial performance. Doctoral dissertation. pp. 243.

Han, J. J., Kim, H. J., \& Yu, J. (2016). Empirical study on relationship between corporate social responsibility and financial performance in Korea. Asian Journal of Sustainability and Social Responsibility, 1(1), 61-76. https://doi.org/10.1186/s41180-016-0002-3

Igalens, J., \& Gond, J. P. (2005). Measuring corporate social performance in France: A critical and empirical analysis of ARESE data. Journal of business ethics, 56(2), 131-148. https://doi.org/10.1007/s10551-0043529-7

Jawadi, F., Jawadi, N., \& Cheffou, A. I. (2019). A statistical analysis of uncertainty for conventional and ethical stock indexes. The Quarterly Review of Economics and Finance, 74(11), 9-17. https://doi.org/10.1016/j.qref.2018.03.002

Kiymaz, H. (2019). Performance evaluation of SRI funds: an analysis of fund types. Accounting and Finance Research, 8(1), 212-221. https://doi.org/10.5430/afr.v8n1p212

Kreander, N., Gray, R.H., Power, D.M., \& Sinclair, C.D. (2005). Evaluating the performance of ethical and non - ethical funds: a matched pair analysis. Journal of Business Finance \& Accounting, 32(7-8), 1465-1493. https://doi.org/10.1111/j.0306-686X.2005.00636.x

Laskar, N. (2018). Impact of corporate sustainability reporting on firm performance: an empirical examination in Asia. Journal of Asia Business Studies, 12(4), 571-593. https://doi.org/10.1108/JABS-11-2016-0157

Lee, D. D., Faff, R. W., \& Langfield-Smith, K. (2009). Revisiting the vexing question: does superior corporate social performance lead to improved financial performance? Australian Journal of Management, 34(1), 2149. https://doi.org/10.1177/031289620903400103

Leite, P., \& Cortez, M. C. (2018). The performance of European SRI funds investing in bonds and their comparison to conventional funds. Investment Analysts Journal, 47(1), 65-79. https://doi.org/10.1080/10293523.2017.1414911 
Malki, T. E. (2010). Business environment, social responsibility and performance: empirical analysis in the case of Morocco. Doctoral dissertation, Aix-Marseille II. pp.501.

Manrique, S., \& Martí-Ballester, C. P. (2017). Analyzing the effect of corporate environmental performance on corporate financial performance in developed and developing countries. Sustainability, 9(11), 1957. https://doi.org/10.3390/su9111957

Maqbool, S., \& Bakr, A. (2019). The curvilinear relationship between corporate social performance and financial performance: Evidence from Indian companies. Journal of Global Responsibility, 10(1), 87-100. https://doi.org/10.1108/JGR-11-2018-0060

Margolis, J. D., \& Walsh, J. P. (2003). Misery loves companies: rethinking social initiatives by business. Administrative Science Quarterly, 48(2), 268-305. https://doi.org/10.2307/3556659

Masoud, N., \& Hasaleh, A. (2017). Corporate Social Responsibility and Company Performance: An Empirical Analysis of Jordanian Companies Listed on Amman Stock Exchange. British Journal of Education, Society \& Behavioral Science, 29(1), 1-26. https://doi.org/10.9734/BJESBS/2017/30496

Mollet, J. C., \& Ziegler, A. (2014). Socially responsible investing and stock performance: New empirical evidence for the US and European stock markets. Review of Financial Economics, 23(4), 208-216. https://doi.org/10.1016/j.rfe.2014.08.003

Moses, O., Olayinka, M., Ulan, V. J., Janet, O. M. A., \& Ambrose, A. O. (2014). Firms' performance and corporate social disclosures: cross-sectional evidence of Nigerian firms. International Journal of Management Practice, 7(4), 341-365. https://DOI.10.1504/IJMP.2014.065231

Mouatassim, L. H., \& Ibenrissoul, A. (2016). Is there an impact of CSR on the financial performance of the company: Empirical study on Moroccan companies listed on the Casablanca stock Exchange. HAL. pp.14.

Nelling, E., \& Webb, E. (2009). Corporate social responsibility and financial performance: the virtuous circle revisited. Review of Quantitative Finance and Accounting, 32, 197-209. https://doi.org/10.1007/s11156-0080090-y

Ngoc, N. B. (2018). The effect of corporate social responsibility on financial performance: Evidence from credit institutions in Vietnam. Asian Social Science, 14(4), 109-122. https://doi.10.5539/ass.v14n4p109

Preston, L. E., \& O'bannon, D. P. (1997). The corporate social-financial performance relationship: A typology and analysis. Business \& Society, 36(4), 419-429. https://doi.org/10.1177/000765039703600406

Saadaoui, K. (2008). Does ethical commitment penalize performance? Analysis of the performance of socially responsible French funds. Presentation presented at the 5th ADERSE Congress: Transversality of Corporate Social Responsibility, pp.15.

Strouhal, J., Gurvits, N., Nikitina-Kalamäe, M., \& Startseva, E. (2015). Finding the link between CSR reporting and corporate financial performance: Evidence on Czech and Estonian listed companies. Central European Business Review, 4(3), 48-59. https://doi.10.18267/j.cebr.132

Tebini, H. (2013). Relationship between financial performance and social / environmental performance: a critical analysis. Doctoral dissertation, University of Quebec in Montreal. pp. 275.

Wang, Q., Dou, J., \& Jia, S. (2016). A meta-analytic review of corporate social responsibility and corporate financial performance: The moderating effect of contextual factors. Business \& Society, 55(8) ,1083-1121. https://doi.org/10.1177/0007650315584317

Wood, D. J. (1991). Corporate Social Performance Revisited. Academy of Management Review, 16(4), 691-718. https://doi.10.2307/258977

\section{Copyrights}

Copyright for this article is retained by the author(s), with first publication rights granted to the journal.

This is an open-access article distributed under the terms and conditions of the Creative Commons Attribution license (http://creativecommons.org/licenses/by/4.0/). 